\title{
XXVIII. Specific characters of Cygnus Bewickii and C. Ferus
}

\section{William Yarrell Esq. F.L.S.}

To cite this article: William Yarrell Esq. F.L.S. (1830) XXVIII. Specific characters of Cygnus Bewickii and C. Ferus, Philosophical Magazine Series 2, 7:39, 194-194, DOI: 10.1080/14786443008675256

To link to this article: http://dx.doi.org/10.1080/14786443008675256

册 Published online: 13 Jul 2009.

Submit your article to this journal

Џ Article views: 2

Q View related articles $₫$ 


\section{Specific Characters of Cygnus Bewickii and C. Ferus.}

in the walks of this science, and am inclined to pay great deference to his experience and judgement in all matters of observation; and accordingly offer these remarks more in the spirit of inquiry than of controversy, wishing to know more fully his views on the subject of his first two groups of the geological series, and leaving all due room for misunderstandings of the subject, from the mere sketch he has professed to give of it. But I should imagine it possible for him to devote all his time and attention to the subject, and complete a system tolerably perfect, without entering into any statements of opinion hostile to Sacred Writ,

I am afraid I have already trespassed too much on your time; and will therefore subscribe myelf, Your's \&c. Z Z.

[That it is wrong to endeavour to represent divine revelation as dependent on any views of natural philosophy, was the opinion of a distinguished teacher of theology long before the present controversies had arisen.-EDiT.

"The Natural Philosophy of the Pentateuch ought not to induce us to reject it. It is not at all likely that God, in order to enable a man to be a lawgiver of the Jews, should reveal to him all the causes of the phæno. mena of nature. But why, you will say, did Moses give this as an authentic account of the creation? Suppose I answer, I do not know? It seems to me as if that would be no sufficient reason for rejecting our whole system of religions dispensations.-Suppose I answer, Moses might be an inspired writer as a religious minister, and be left to his own notions, or to notions established in his time, as a natural philosopher: and yet he always might write and speak in those different characters, in one and the same tone and style? Even that would be sufficient to hinder our rejecting the Pentateuch."-Lectures in Divinity by Dr. John Hey, Norrisian Professor of Divinity in the University of Cambridge, from 1780 to 1795, vol.i. p. 196.]

XXVIII. Specific Characters of Cygnus Berwickii and C. Ferus. By W. YarRell, Esq. F.L.S. \&c.

To the Editors of the Philosophical Magazine and Annals.

THE great similarity in the external appearance of our two wild swans, will render a slight alteration necessary in the specific characters hitherto attached to the Anas Cysnus (ferus) of Linnæus.

In addition, therefore, to your obliging notice of Bewick's swan, in the Philosophical Magazine of last month, may I request insertion for the following short distinguishing characters of both species:

Ordo, Natatores, Illiger.-Fam. Anatidæ, Leach.-Gen. Cygnus, Meyer. C. Beroickii, rostro semicylindrico atro, basi aurantiacâ, corpore albo, caudâ rectricibus 18 , pedibus nigris.

C. ferus, rostro semicylindrico atro, basi lateribusque (his ultra nares) flavis, corpore albo, caudâ rectricibus 20 , pedibus nigris. I am, \&c.

Ryder Street, St. James's, Feb. 6, $1830 . \quad$ William YarRer.L.

XXIX. On 